\title{
A STUDY ON SOMATIC DNA DAMAGES IN HYPERTENSIVE YOUNG ADULTS AND ITS CORRELATION WITH BIOCHEMICAL AND DEMOGRAPHIC PARAMETERS
}

\author{
Biochemistry \\ Sumina Cheriyan Research Scholar, Meenakshi University, Chennai, TamilNadu \\ Deepti G N* Associate Professor, Believers Church Medical College Hospital, Thiruvalla \\ *Corresponding Author
}

\begin{tabular}{ll}
\hline Dinesh Roy D & Genitika, Centre for advanced genetic studies, Pettah, Thiruvananthapuram. \\
\hline Jaideep Mahendra & $\begin{array}{l}\text { Associate Professor, Department of Periodontics, Meenakshiammal Dental College, } \\
\text { Chennai }\end{array}$ \\
\hline
\end{tabular}

Associate Professor, Department of Biochemistry, Jubilee Mission Medical College, Thrissur

\section{ABSTRACT}

Introduction: Incidence of hypertension is increasing in young population. Aggressive control is mandatory to preserve and protect public health in India. Several socio-demographic, anthropometric, environmental, lifestyle, biochemical and genetic factors contribute for the development of hypertension in young adults. Hypertension and its chronic complications are also linked to oxidative stress and DNA damage. Methods: The cross sectional study involves 180 young hypertensives between the age group of $18-39$ years and 140 apparently healthy age and sex matched controls. After obtaining relevant history, anthropometric measurements were taken. Socio-demographic characters were recorded using proforma. After taking written informed consent, five ( $5 \mathrm{ml}$ ) of venous blood was collected after $8-12$ hours of fasting. $2 \mathrm{ml}$ of blood was transferred aseptically to a sodium heparinised vacutainer for evaluating somatic DNA damages by Cytokinesis-block Micronuclei assay (CBMN assay). Remaining 3 ml of blood is allowed to clot; serum separated and was used for other biochemical investigations such as fasting blood sugar, lipid profile, urea, creatinine and malondialdehyde (MDA). Statistical analysis done using SPSS software. Results: Fasting blood sugar, Total cholesterol, LDL cholesterol, triglycerides, urea and creatinine were significantly elevated in young hypertensives. Oxidative stress and DNA damage is significantly elevated in young hypertensives compared to control group. BMI and abdominal circumference are also significantly elevated in young hypertensive adults compared to control group. Conclusion: Increased oxidative stress and DNA damage in young hypertensives contribute to the complications associated with hypertension.

\section{KEYWORDS}

\section{DNA damage, Hypertension, CBMN frequency, Malondialdehyde}

\section{INTRODUCTION}

Hypertension (HTN) is a global public health problem affecting nearly 1 billion people worldwide. High blood pressure (HBP) is attributed to around $54 \%$ of stroke and $47 \%$ of ischemic heart disease worldwide (Rodgers et al 2000) [1]. In India, the prevalence rate of hypertension has been found to be increasing in urban, rural and tribal population and it is considered as an important modifiable risk factor for cardiovascular diseases (CVD). CVD accounts for one in every eight deaths worldwide (WHO 2002) [2]. The exact etiology of high blood pressure is difficult to describe as only about $5 \%$ of hypertensive patients are having a known cause. The remaining $95 \%$ has no identifiable cause and is referred as essential hypertension. Essential Hypertension (EH) can be diagnosed when the systolic BP ranging between 140 and $160 \mathrm{~mm} \quad \mathrm{Hg}$ and/or diastolic BP between 95 and $100 \mathrm{~mm} \mathrm{Hg}$ at three random checks and need medical monitoring and lifestyle changes (Chobanian 2003) [3]. The important contributors of hypertension are decreased physical activities combined with increased mental tension which is commonly seen in individuals with sedentary type of occupation.

Although HTN is more prevalent in older population, now-a day an increasing incidence is seen in young adults affecting approximately 19 per cent of the young adult population worldwide (Shriver 2011) [4].Hypertension is associated with increased vascular oxidative stress. However, it is still unclear whether oxidative stress is a cause or a result of hypertension (Grossman 2008) [5]. DNA damage occurs more in hypertensives than in normal population. The molecular basis of hypertension is complex and more than 50 genes have been indicated in blood pressure regulation (Garbers and Dubois 1999) [6].

Oxidative stress and DNA damage may be the link between HTN and its chronic complications. DNA damages are frequent in cells that are exposed to oxidative stress. Increased oxidative status can cause lipid peroxidation in cell membranes which in turn can damage membrane proteins, or cause DNA fragmentation. All these effects may cause in the loss of contractile function of heart and in turn result in severe myocardial cell damage. Acute hypertension can stimulate the release of oxygen-free radicals and this in turn might mediate vascular damages in hypertensive subjects (De Bruyn et al 1994) [7]. Study by Fogarty et al (2011) showed that life style factors such as diet and physical activity can also influence DNA damage (Fogarty et al 2011) [8]

As hypertension is creeping down to young adults, early surveillance and prompt treatment is necessary to prevent future cardiac events. No systematic studies were conducted to evaluate oxidative stress and somatic DNA damages in young hypertensives and its correlation with that of various biochemical \& demographical factors. Hence the present study is undertaken to evaluate the role of such factors in hypertensive young adults.

\section{MATERIALS \& METHODS}

Inclusion criteria: This cross sectional study included hypertensive young adults who has attended the OPD of a tertiary care hospital in Trivandrum \& was referred to Genetika, a cytogenetic laboratory in Kerala. 180 hypertensive young adults between the age group 18-39 were selected as study subjects and 140 age and sex matched healthy subjects were selected as control group.

Exclusion criteria: Patients with history of exposure to ionic radiation, chemotherapy \& other mutagenic agents and subjects with any form of malignancy and other chronic disorders were excluded from this study. Subjects above the age of 40 and below the age of 18 are excluded.

Sample size: The sample size for the present study was calculated by taking most probable prevalence of hypertension as $40 \%$ and the minimum sample size calculated is 150 (Zaveri et al 2013) [9]

Ethical Clearance: The study was approved by Institutional Ethics Committee (Human studies) meeting conducted on November 22, 2014 (Reg no. 18/IEC/GTKA) at Genetika, Centre for Advanced Genetic Studies, Thiruvananthapuram, Kerala.

Using a well-defined proforma, socio-demographic and clinical characteristics of the subjects were recorded. Anthropometric measurements are taken and analysed. Five $\mathrm{ml}$ of peripheral blood was 
collected aseptically by venipuncture from each patient. For quantifying the extent of somatic DNA damages by Cytokinesis-Block Micronuclei (CBMN) assay, $2 \mathrm{ml}$ of blood was transferred to sodium heparinized vacutainers. The remaining $3 \mathrm{ml}$ of blood was then allowed to clot and serum separated immediately.

Biochemical investigations such as fasting plasma glucose, Plasma Lipid Profile (Total cholesterol, Triglycerides, HDL Cholesterol, LDL cholesterol), Blood Urea and Creatinine were estimated in fully automated chemistry analyser using commercial assay kits. MDA, the marker of oxidative stress was estimated by thiobarbituric acid (TBA) method according to (Sato et al 1979) [10]

Somatic DNA damages by CBMN assay: 5-6 drops of heparinized blood were added to a culture tube containing $10 \mathrm{ml}$ of RPMI 1640 media supplemented with $15 \%$ of fetal bovine serum and $10 \mu \mathrm{g} / \mathrm{ml}$ phytohemagluttinin (PHA). Cytochalasin B was added to the cultures at a final concentration of $4.5 \mu \mathrm{g} / \mathrm{ml}$ after 44 th hour of initiation of cells with PHA. Cells were harvested after 72 hour incubation and they were treated with a hypotonic solution $(0.075 \mathrm{M} \mathrm{KCl})$ for 3 minutes and fixed in fresh fixative solution (methanol: acetic acid, 3:1). The cells were dropped onto microscopic slides and were air dried and stained with $10 \%$ Giemsa. Micro nucleated cells were analyzed under a microscope at $100 \mathrm{X}$ magnification. The number of micronuclei of not less than 1000 binucleated cells were scored and the distribution of micronuclei among binucleated cells was recorded (Fenech 1993) [11]

Statistical analysis: Statistical analysis done using SPSS software (Version 16). Independent $t$ test was done to study the significance of means obtained. P value $<0.05$ is taken as statistically significant. Pearson correlation was also done for assessing the correlation of various biochemical and anthropometric parameters with mean CBMN frequency. Statistical analysis of categorical variables done by Chi-square test and the strength of association was established by Odds ratio with $95 \%$ confidence interval (CI). Variables which were found significantly associated with dependent variable in univariate analysis were subjected to multivariate analysis of binary logistic regression and multiple linear regression to predict independent relationship.

\section{RESULTS:}

180 young hypertensives between the age group 18-39 years and 140 healthy age and sex matched controls were included in the present study.

Table 1 shows the comparison of biochemical parameters between cases and controls. Biochemical parameters such as FBS, Total cholesterol, LDL cholesterol, Triglycerides, Urea, Creatinine showed a statistical significant difference $(\mathrm{p}$ value $<0.05)$

Table 1:- Comparison of biochemical parameters in cases and controls

\begin{tabular}{|c|c|c|c|c|c|c|}
\hline \multirow[t]{2}{*}{ Parameters } & \multicolumn{2}{|c|}{ Cases $(n=180)$} & \multicolumn{2}{|c|}{ Controls $(n=140)$} & \multirow[t]{2}{*}{$\mathrm{t}$} & \multirow[t]{2}{*}{$\mathrm{p}$} \\
\hline & Mean & SD & Mean & SD & & \\
\hline FBS (mg/dl) & 170.36 & 108.31 & 91.51 & 9.97 & 8.583 & $<0.001$ \\
\hline $\begin{array}{l}\text { Total Cholesterol } \\
(\mathrm{mg} / \mathrm{dl})\end{array}$ & 254.11 & 42.61 & 176.68 & 14.49 & 20.592 & $<0.001$ \\
\hline $\begin{array}{l}\text { HDL Cholesterol } \\
(\mathrm{mg} / \mathrm{dl})\end{array}$ & 37.96 & 5.08 & 48.48 & 7.79 & -14.579 & $<0.001$ \\
\hline $\begin{array}{l}\text { LDL Cholesterol } \\
(\mathrm{mg} / \mathrm{dl})\end{array}$ & 132.92 & 20.92 & 109.75 & 15.19 & 11.033 & $<0.001$ \\
\hline $\begin{array}{l}\text { Triglyceride } \\
(\mathrm{mg} / \mathrm{dl})\end{array}$ & 180.31 & 24.05 & 126.04 & 16.50 & 22.842 & $<0.001$ \\
\hline Urea (mg/dl) & 25.97 & 3.77 & 14.75 & 3.32 & 27.803 & $<0.001$ \\
\hline $\begin{array}{l}\text { Creatinine } \\
(\mathrm{mg} / \mathrm{dl})\end{array}$ & 4.97 & 2.18 & 0.87 & 0.18 & 22.204 & $<0.001$ \\
\hline
\end{tabular}

SD:- Standard deviation

Table 2 shows the comparison of mean CBMN frequency and mean MDA among cases and controls. The mean values of MDA \& CBMN frequency are higher in cases compared to controls and the difference is statistically significant ( $\mathrm{p}$ value $<0.05$ ).

Table 2: Comparison of mean MDA and mean CBMN frequency in cases and controls

\begin{tabular}{|c|c|c|c|c|c|c|}
\hline Parameters & \multicolumn{2}{|c|}{ Cases (n=180) } & \multicolumn{2}{|c|}{ Controls (n=140) } & \multirow{2}{*}{$\mathrm{p}$} & $\mathrm{p}$ \\
\cline { 2 - 5 } & Mean & SD & Mean & SD & & \\
\hline MDA & 3.07 & 0.38 & 1.26 & 0.52 & 35.828 & $<0.001$ \\
\hline $\begin{array}{c}\text { Mean } \\
\text { CBMN } \\
\text { frequency }\end{array}$ & 12.72 & 0.85 & 9.94 & 0.54 & 33.688 & $<0.001$ \\
\hline
\end{tabular}

SD:- Standard Deviation

Table 3 shows the comparison of continuous variables of demographic and anthropometric parameters between cases and controls. Anthropometric parameters such as BMI and abdominal circumference showed a statistical significant difference with a $p$ value $<0.05$.

Table 3: Comparison of demographic and anthropometric parameters in cases and controls

\begin{tabular}{|c|c|c|c|c|c|c|}
\hline \multirow{2}{*}{ Parameters } & \multicolumn{2}{|c|}{ Cases $(\mathrm{n}=180)$} & \multicolumn{2}{c|}{ Controls $(\mathrm{n}=140)$} & $\mathrm{t}$ & $\mathrm{p}$ \\
\cline { 2 - 6 } & Mean & SD & Mean & SD & & \\
\hline Age & 36.55 & 6.23 & 37.34 & 5.81 & -1.153 & 0.250 \\
\hline Height $(\mathrm{m})$ & 1.60 & 0.10 & 1.59 & 0.08 & 1.346 & 0.179 \\
\hline Weight $(\mathrm{kg})$ & 70.50 & 12.40 & 57.84 & 7.61 & 10.624 & $<0.001$ \\
\hline BMI $\left(\mathrm{kg} / \mathrm{m}^{2}\right)$ & 27.52 & 4.69 & 22.94 & 2.48 & 10.455 & $<0.001$ \\
\hline $\begin{array}{c}\text { Abdominal } \\
\text { circumference } \\
(\mathrm{cm})\end{array}$ & 105.07 & 18.56 & 93.53 & 8.74 & 6.794 & $<0.001$ \\
\hline
\end{tabular}

SD:- Standard Deviation

Table 4 displays the statistical analysis of categorical variables of demographic parameters such as age, sex, residence, education \& occupational type by chi square test. Observable statistical difference was observed for education and occupational type ( $p$ value $<0.05$ ). Odds ratios of the corresponding variables are also calculated for assessing the strength of association of these variables with hypertension.

Table 4: Statistical analysis of demographic characters done by chi square test

\begin{tabular}{|c|c|c|c|c|c|c|c|c|c|}
\hline \multirow{2}{*}{$\begin{array}{c}\text { Categ } \\
\text { ory }\end{array}$} & \multirow[t]{2}{*}{ Variables } & \multirow{2}{*}{\begin{tabular}{|c|} 
Case \\
$\mathrm{N}$ \\
\end{tabular}} & \multirow{2}{*}{\begin{tabular}{|c|} 
Control \\
$\%$ \\
\end{tabular}} & \multirow[b]{2}{*}{$\mathrm{N}$} & \multirow[b]{2}{*}{$\%$} & \multirow[t]{2}{*}{$\mathrm{p}$} & \multirow[t]{2}{*}{ OR } & \multicolumn{2}{|c|}{$95 \%$ CI for } \\
\hline & & & & & & & & \multirow[t]{5}{*}{ Lower } & \multirow{5}{*}{$\begin{array}{c}\text { Upp } \\
\text { er }\end{array}$} \\
\hline \multirow[t]{4}{*}{ Age } & $<25$ & 12 & 6.7 & 6 & 4.3 & \multirow[t]{4}{*}{0.06} & & & \\
\hline & $26-30$ & 24 & 13.3 & 11 & 7.9 & & & & \\
\hline & $31-35$ & 93 & 51.7 & 93 & 66.4 & & & & \\
\hline & $36+$ & 51 & 28.3 & 30 & 21.4 & & & & \\
\hline \multirow[t]{3}{*}{ Sex } & Male & 93 & 51.7 & 79 & 56.4 & \multirow[t]{3}{*}{0.397} & \multirow[t]{3}{*}{1.212} & \multirow[t]{7}{*}{\begin{tabular}{|l|}
0.77 \\
\end{tabular}} & \multirow[t]{7}{*}{1.88} \\
\hline & Female & 87 & 48.3 & 61 & 43.6 & & & & \\
\hline & Total & 180 & 100 & 140 & 100 & & & & \\
\hline \multirow{4}{*}{$\begin{array}{c}\text { Reside } \\
\text { nce }\end{array}$} & Urban & 93 & 51.7 & 85 & 60.7 & \multirow[t]{4}{*}{0.187} & & & \\
\hline & Rural & 64 & 35.6 & 44 & 31.4 & & & & \\
\hline & Coastal & 23 & 12.8 & 11 & 7.9 & & & & \\
\hline & Total & 180 & 100 & 140 & 100 & & & & \\
\hline \multirow[t]{2}{*}{$\begin{array}{c}\text { Educa } \\
\text { tion }\end{array}$} & $\begin{array}{c}\text { High } \\
\text { school or } \\
\text { below }\end{array}$ & 113 & 62.8 & 57 & 40.7 & \multirow[t]{2}{*}{$<0.001$} & \multirow[t]{2}{*}{2.46} & \multirow[t]{2}{*}{\begin{tabular}{|l|}
1.56 \\
\end{tabular}} & \multirow[t]{2}{*}{3.85} \\
\hline & $\begin{array}{c}\text { Higher } \\
\text { secondar } \\
\text { y and } \\
\text { above }\end{array}$ & 67 & 37.2 & 83 & 59.3 & & & & \\
\hline \multirow[t]{2}{*}{$\begin{array}{l}\text { Occup } \\
\text { ational } \\
\text { type }\end{array}$} & \begin{tabular}{|c|} 
Sedentar \\
$\mathrm{y}$
\end{tabular} & 87 & 48.3 & 51 & 36.4 & \multirow[t]{2}{*}{0.033} & \multirow[t]{2}{*}{1.63} & \multirow[t]{2}{*}{\begin{tabular}{|l|}
1.04 \\
\end{tabular}} & \multirow[t]{2}{*}{3.95} \\
\hline & $\begin{array}{c}\text { Non } \\
\text { sedentar } \\
\mathrm{y}\end{array}$ & 93 & 51.7 & 89 & 63.6 & & & & \\
\hline
\end{tabular}

OR:-Odds ratio; CI:- Confidence interval

Table 5 shows the Pearson correlation of CBMN frequency with other parameters. BMI, abdominal circumference, systolic blood pressure, diastolic blood pressure, fasting blood sugar, Total cholesterol, LDL- 
cholesterol, triglycerides, urea, creatinine and MDA showed a positive correlation with CBMN frequency whereas HDL cholesterol showed a negative correlation with $\mathrm{CBMN}$ frequency.

Table 5: Pearson correlation of CBMN frequency with other parameters

\begin{tabular}{|c|c|c|}
\hline $\begin{array}{c}\text { Correlation of CBMN frequency } \\
\text { with other parameters }\end{array}$ & Pearson Correlation $\mathrm{r}$ & $\mathrm{p}$ \\
\hline MDA & $.869^{* *}$ & $<0.001$ \\
\hline Height $(\mathrm{m})$ & 0.077 & 0.171 \\
\hline Weight $(\mathrm{kg})$ & $.169^{* *}$ & 0.002 \\
\hline BMI $\left(\mathrm{kg} / \mathrm{m}^{2}\right)$ & $.123^{*}$ & 0.028 \\
\hline Abdominal circumference $(\mathrm{cm})$ & $.304^{* *}$ & $<0.001$ \\
\hline Systolic Pressure $(\mathrm{mmHg})$ & $.686^{* *}$ & $<0.001$ \\
\hline Diastolic pressure $(\mathrm{mmHg})$ & $.685^{* *}$ & $<0.001$ \\
\hline FBS $(\mathrm{mg} / \mathrm{dl})$ & $.480^{* *}$ & $<0.001$ \\
\hline Total cholesterol $(\mathrm{mg} / \mathrm{dl})$ & $.377^{*} *$ & $<0.001$ \\
\hline HDL $(\mathrm{mg} / \mathrm{dl})$ & $-.572^{* *}$ & $<0.001$ \\
\hline LDL $(\mathrm{mg} / \mathrm{dl})$ & $.494 * *$ & $<0.001$ \\
\hline Triglycerides $(\mathrm{mg} / \mathrm{dl})$ & $.229^{* *}$ & $<0.001$ \\
\hline Urea $(\mathrm{mg} / \mathrm{dl})$ & $.454 * *$ & $<0.001$ \\
\hline Creatinine $(\mathrm{mg} / \mathrm{dl})$ & $.701^{* *}$ & $<0.001$ \\
\hline
\end{tabular}

Table 6 shows multiple linear regression of CBMN frequency. Regression analysis showed that fasting blood sugar, LDL cholesterol, HDL cholesterol, creatinine and MDA are independent predictors of DNA damages in hypertensive young adults.

Table 6:- Multiple Linear Regressions for Mean CBMN frequency

\begin{tabular}{|c|c|c|c|c|c|}
\hline & \multicolumn{2}{|c|}{$\begin{array}{c}\text { Unstandardized } \\
\text { Coefficients }\end{array}$} & \begin{tabular}{|c|} 
Standardized \\
Coefficients
\end{tabular} & \multirow[t]{2}{*}{$\mathrm{t}$} & \multirow[t]{2}{*}{$\mathrm{p}$} \\
\hline & B & Std. Error & Beta & & \\
\hline (Constant) & 4.899 & 0.464 & & 10.567 & 0.000 \\
\hline FBS (mg/dl) & 0.002 & 0.001 & 0.073 & 2.911 & 0.004 \\
\hline $\begin{array}{c}\text { HDL } \\
\text { cholesterol } \\
(\mathrm{mg} / \mathrm{dl})\end{array}$ & -0.022 & 0.005 & -0.115 & -4.02 & 0.000 \\
\hline $\begin{array}{c}\text { LDL } \\
\text { cholesterol } \\
(\mathrm{mg} / \mathrm{dl})\end{array}$ & 0.009 & 0.002 & 0.13 & 5.001 & 0.000 \\
\hline Urea $(\mathrm{mg} / \mathrm{dl})$ & 0.014 & 0.009 & 0.042 & 1.678 & 0.094 \\
\hline $\begin{array}{l}\text { Creatinine } \\
(\mathrm{mg} / \mathrm{dl})\end{array}$ & 0.074 & 0.019 & 0.125 & 3.918 & 0.000 \\
\hline MDA (U/L) & 0.462 & 0.074 & 0.296 & 6.251 & 0.000 \\
\hline
\end{tabular}

Dependent variable:- Mean CBMN frequency

\section{DISCUSSION:}

Hypertension in young adults has found to be doubled during the past 10 years and has demanded a re-evaluation of approach towards their evaluation, investigation and treatment. Younger the patient, greater is the likelihood for a secondary cause. As oxidative stress is implicated in the pathogenesis of hypertension, the present study focussed on DNA damages in young adults with hypertension and its correlation with biochemical and demographic parameters.

In the .present study, MDA levels are significantly high in young hypertensives compared to normal subjects demonstrating increased oxidative stress in young hypertensives. A study by (Logacheva et al 2001) [12] observed an increased production of oxidant free radicals in patients with ischemic heart disease. Oxidative stress is a promoter for the primary abnormality in the vascular smooth muscle cell function, which in turn alters the tone in the arterial resistance vessels, increases systemic vascular resistance and thereby increases blood pressure. Endothelial function is impaired as a result of increased oxidative stress which in turn mediates vascular disease. Oxidative stress which is produced by intracellular ROS results in DNA damages, DNA strand breaks \& chromosomal aberrations, which played an important role in atherosclerosis and coronary artery disease (Andreassi 2008) [13].

In the present study somatic DNA damages are found to be significantly increased in young hypertensives which may have serious consequences if left unrepaired. A study by Subhash et al (2010) [14] observed a close relation of oxidative damage with the development and complication of essential hypertension. The accumulation of DNA damages is of concern as it increases the chances of cardiovascular disease morbidity and mortality. Most of diseases of genetic origin commences as a consequence of DNA damage. In literature, numerous studies have demonstrated increased genetic damage in patients with heart disease. Study by Botto et al 2001 [15] observed that coronary artery disease (CAD) patients showed 5.6 folds increase of micronuclei while Andreassi et al 2005 [16] had reported 3.1 folds increase of micronuclei frequency in CAD patients. A study by Mahmoudi et al 2006 [17] observed oxidative DNA damages in atherosclerotic plaque cells indicating its role in inducing CAD.

Simon et al 2010 [18] in their studies on cardio metabolic syndrome observed that total cholesterol, triglyceride and LDL cholesterol were significantly higher and HDL cholesterol was significantly lower in CAD patients compared to the normal subjects. A similar finding was observed in the present study emphasizing the association of dyslipidemia with hypertension. A positive correlation is observed for total cholesterol, triglycerides, LDL cholesterol and a negative correlation for HDL cholesterol with $\mathrm{CBMN}$ frequency pointing out that dyslipidemia is a contributing factor for increased oxidative DNA damages in young hypertensives which is consistent with the results of study by Huang et al 2013 [19]. Our study also observed a positive association of fasting blood sugar with blood pressure, which is supported by the results of previous study by Di Bonito et al 2011 [20]. A positive correlation was observed for fasting blood sugar and CBMN frequency demonstrating increased DNA damages in hyperglycemic subjects.

The mean values of serum urea and creatinine are increased in cases compared to controls and the difference was statistically significant ( $p$ value $<0.05$ ) emphasising the association of hypertension with chronic kidney disease which is in agreeable with the studies by Zhang et al 2013 [21] and Mittal 2014 [22].

The mean values of BMI and abdominal circumference was higher in cases compared to controls in the present study clearly demonstrating the association of obesity with hypertension which is supported by the observations of studies by Gupta and Kapoor 2010 and Movahed et al 2016 [23, 24]. While performing Pearson correlation, BMI and abdominal circumference showed a positive correlation with CBMN frequency pointing out that DNA damages are significantly higher in obese individuals.

The present study observed a strong association of socio-demographic characters such as education $(\mathrm{OR}=2.46)$ and sedentary occupation $(\mathrm{OR}=1.63)$ with hypertension. Lower education group is 2.46 times more possible to develop hypertension than higher education group in the present study which is supported by the study by Leng et al 2015 [25] reporting low education as an important predictor of CVD and hypertension. Gao et al 2017 [26] observed that hypertension is highly prevalent in individuals with sedentary occupation which is agreeable with our study.

In the present study, maximum number of hypertensive young adults were in the age group 31-35 and males were predominantly affected than females in this age group. Analysis by Vaccarino et al 1995 [27] showed that young age group women had lower levels of cardiovascular risk factors compared to men and when age advances, women had more risk than men.

\section{CONCLUSION:}

Present study shows that lower educational level and sedentary occupation is associated with hypertension in young adults. There is increased oxidative stress and DNA damages in young hypertensives which can contribute to the complications associated with hypertension.

\section{Future perspectives:}

- More studies are needed for a better understanding of DNA damage in vascular dysfunction in order to limit complications of hypertension in young adults and identify new targets for drug development.

- Studies on DNA repair efficiency and genetic polymorphism of genes involved in DNA repair (XRCC1 \& XRCC 4) is 
recommended in young hypertensives, since it is significantly associated with the risk of cardiovascular disease and elevated levels of chromosomal damage

\section{REFERENCES}

1. Rodgers A, Lawes C, MacMahon S. Reducing the global burden of blood pressurerelated cardiovascular disease. Journal of hypertension. Supplement: official journal of the International Society of Hypertension. 2000 May; 18(1):S3-6.

2. World Health Organization. The world health report 2002: reducing risks, promoting healthy life. World Health Organization; 2002

3. Chobanian AV. National heart, lung, and blood institute joint national committee on prevention, detection, evaluation, and treatment of high blood pressure; national high blood pressure education program coordinating committee: the seventh report of the joint national committee on prevention, detection, evaluation, and treatment of high blood pressure: the JNC 7 report. Jama. 2003;289:2560-72.

4. Shriver EK.NIH News, National Institute of Child Health \& Human Development (NICHD) Embargoed for Release. Available at http.//www.nichd.nih.gov. Cited May 26, 2011 ) Embargoed for Release. Availableathip./www. 2011

5. Grossman E. Does increased oxidative stress cause hypertension?. Diabetes care. 2008 Feb 1;31(Supplement 2):S185-9

6. Garbers DL, Dubois SK. The molecular basis of hypertension. Annual review of biochemistry. 1999 Jul;68(1):127-55.

7. De Bruyn VH, Nuns DW, Cappelli-Biggazzi M, Dole WR, Lamping KG. Effect of acute hypertension in the coronary vessels. J Hypertens 1994; 12: 163-172

8. Fogarty MC, Hughes CM, Burke G, Brown JC, Trinick TR, Duly E, Bailey DM, Davison GW. Exercise-induced lipid peroxidation: implications for deoxyribonucleic acid damage and systemic free radical generation. Environmental and molecular damage and systemic free radical
mutagenesis. 2011 Jan;52(1):35-42.

9. Zaveri, A., Lehmann, J., Auer, S., Hassan, M.M., Sherif, M.A. and Martin, M., 2013. Publishing and interlinking the global health observatory dataset. Semantic Web, 4(3), pp.315-322).

10. Sato, Y., Hotta, N., Sakamoto, N., Matsuoka, S., Ohishi, N. and Yagi, K., 1979. Lipid peroxide level in plasma of diabetic patients. Biochemical medicine, 21(1), pp.104-107.

11. Fenech, M., 1993. The cytokinesis-block micronucleus technique: a detailed description of the method and its application to genotoxicity studies in human populations. Mutation Research/Fundamental and Molecular Mechanisms of Mutagenesis, 285(1), pp.35-44.

12. Logacheva IV, Leshchinskiī LA, Romanova ZD, Găsin IR, Perevalov AP, Karbasnikova $\mathrm{GV}$. Use of antioxidants and trimetazidine in preparation of patients with ischemic heart GV. Use of antioxidants and trimetazidine in preparation of patients with ischemic
disease for coronary angiography. Klinicheskaiameditsina. 2001;79(1):30-3.

13. Andreassi MG, Molecular mechanisms of hypertension--reactive oxygen species and antioxidants: a basic science update for the clinician. . J Mol. Med 2008;86:1033-1043.

14. Subhash, P. et al. Total antioxidant status and oxidative DNA damage in a South Indian population of essential hypertensives. J. Hum. Hypertens. 24, 475-482 (2010).

15. Botto, N., Rizza, A., Colombo, M.G., Mazzone, A.M., Manfredi, S., Masetti, S., Clerico, A., Biagini, A. and Andreassi, M.G., 2001. Evidence for DNA damage in patients with coronary artery disease. Mutation Research/Genetic Toxicology and Environmental Mutagenesis, 493(1-2), pp.23-30.

16. Andreassi, M.G., Botto, N., Simi, S., Casella, M., Manfredi, S., Lucarelli, M., Venneri, L., Biagini, A. and Picano, E., 2005. Diabetes and chronic nitrate therapy as codeterminants of somatic DNA damage in patients with coronary artery disease. Journal of Molecular Medicine, 83(4), pp.279-286.

17. Mahmoudi M, Mercer J, Bennett M. DNA damage and repair in atherosclerosis. Cardiovasc Res. 2006;71:259-268

18. Simon AS, Roy DD. Jayapal V, Vijayakumar T. Biochemical and genetic studies on cardiometabolic syndrome. Ind J ClinBiochem 2010;25 (2):164-168

19. Huang Q, Qin L, Dai S, et al. AIP1 suppresses atherosclerosis by limiting hyperlipidemia-induced inflammation and vascular endothelial dysfunction. ArteriosclerThrombVasc Biol. 2013;33(4): 795-804.

20. Di Bonito $P$, et al. Fasting plasma glucose and clustering of cardiometabolic risk factors in normoglycemic outpatient children and adolescents. Diabetes Care. 2011;34:1412. doi: $10.2337 / \mathrm{dc} 10-1783$

21. Zhang YP, Zuo XC, Huang ZJ, Kuang ZM, Lu MG, Duan DD, Yuan H. The impact of blood pressure on kidney function in the elderly: a cross-sectional study. Kidney and Blood Pressure Research. 2013;38(2-3):205-16

22. Mittal, Y., 2014. Serum creatinine level in hypertensive patients: A study from Uttarakhand, India. International Journal of Pharmaceutical Sciences and Research, 5(7), p.2955.

23. Gupta S, Kapoor S. Sex differences in blood pressure levels and its association with obesity indices: who is at greater risk. Ethnicity \& disease. 2010 Mar 18;20(4):370.

24. Movahed MR, Lee JZ, Lim WY, Hashemzadeh M, Hashemzadeh M. Strong independent association between obesity and essential hypertension. Clinical obesity. 2016 Jun;6(3): 189-92

25. Leng, B., Jin, Y., Li, G., Chen, L. and Jin, N., 2015. Socioeconomic status and hypertension: a meta-analysis. Journal of hypertension, 33(2), pp.221-229

26. Gao, S. and Liu, J., 2017. Association between circulating oxidized low-density lipoprotein and atherosclerotic cardiovascular disease. Chronic diseases and translational medicine, 3(2), pp.89-94

27. Vaccarino, V., Borgatta, A., Gallus, G. and Sirtori, C.R., 1995. Prevalence of coronary heart disease risk factors in northern-Italian male and female employees. European heart journal, 16(6), pp.761-769. 